\section{Analisis Sistem Pemerintahan di Indonesia, Masih Relevankah Konsep Negara Kesatuan?}

\author{
Ika Arinia Indriyany \\ Program Studi Ilmu Pemerintahan, \\ Universitas Sultan Ageng Tirtayasa. \\ Korespodensi Penulis. E-mail: \\ ikaarinia@fisip-untirta.ac.id
}

\begin{abstract}
Abstrak
Tulisan ini akan membahas secara mendalam mengenai alternatif bentuk negara di Indonesia. Selama ini bentuk negara Indonesia adalah Negara Kesatuan dan perdebatan mengenai bentuk negara lain yaitu federalisme merupakan perbincangan yang cenderung dihindari, karena dianggap sebagai potensi ancaman persatuan bangsa dan negara. Terlepas dari itu, bagaimana pun wacana mengenai federalisme ini pernah beberapa kali muncul dalam sejarah Indonesia. Demi kepentingan akademis dalam rangka pengembangan keilmuan dan pencarian alternatif baru yang ideal dalam pengelolaan Negara Indonesia, wacana ini penulis munculkan kembali. Tulisan ini juga bertujuan untuk menambah khasanah mengenai wacana federalisme, sebuah wacana yang dianggap terlarang jika dibicarakan di Indonesia
\end{abstract}

Kata kunci: Kesatuan, Sentralisasi, Federalisme, Desentralisasi

\section{Analysis of Government Systems in Indonesia, Still Relevant to the Concept of the Unitary State?}

\begin{abstract}
This paper will discuss in depth about alternative forms of state in Indonesia. So far, the form of the state of Indonesia is a unitary state and debates about the form of other countries, namely federalism, are talks that tend to be avoided, because they are considered as potential threats to the unity of the nation and state. Apart from that, after all the discourse about federalism has appeared several times in Indonesian history. For the sake of academic interest in the context of scientific development and the search for ideal new alternatives in the management of the State of Indonesia, the author's discourse reappears. This paper also aims to increase the treasury of the discourse of federalism, a discourse that is considered forbidden if discussed in Indonesia
\end{abstract}

Keywords: Unity, Centralization, Federalism, Decentralization

\section{A. PENDAHULUAN}

Perdebatan mengenai bentuk negara Indonesia muncul secara serius pada sidang BPUPKI dalam rangka mempersiapkan kemerdekaan Indonesia. BPUPKI merupakan lembaga yang dibentuk oleh Jepang atas responnya terhadap kekalahan yang mereka derita dari Amerika Serikat di Perang Asia Timur Raya pada September 1944. Pasca kekalahan tersebut, Jepang memberikan janji pada Indonesia bahwa Indonesia akan diberikan kemerdekaan. Dan 
pada tanggal 1 Maret 1945 dibentuklah sebuah badan khusus yang memang memiliki tugas untuk melakukan persiapan kemerdekaan indonesia. Dalam rangka melakukan persiapan kemerdekaan BPUPKI menjalankan tugas menyelidiki, mempelajari dan mempersiapkan hal penting terkait dengan masalah tata pemerintahan.

BPUPKI, yang diketuai oleh dr.KRT Radjiman Wediodiningrat, beranggotakan tokoh - tokoh pergerakan nasional yang berasal dari berbagai daerah dan aliran (Sularto dan Yunarti, 2010). BPUPKI ini melakukan sidang sebanyak 2 kali dan bentuk negara Indonesia dibahas pada sidang pertama (29 Mei - 1 Juni 1945). Pada sidang ini terjadi perdebatan serius antara para founding father, apakah negara Indonesia akan menggunakan bentuk negara kesatuan ataukah bentuk negara federal. Bentuk negara menjadi perdebatan serius antara tokoh kemerdekaan karena memang BPUPKI terdiri anggota yang memiliki latar belakang beragam, tidak hanya latar belakang kedaerahan yang beragam, tetapi juga latar belakang keilmuan, aliran yang diyakini dan agama. Latar belakang keilmuan memang diyakini memiliki pengaruh paling besar dalam menentukan pemikiran mengenai bentuk negara.

Tokoh - tokoh yang sempat mengenyam bangku sekolah di luar negeri seperti Moh. Hatta cenderung akan memilih federalisme sebagai bentuk negara dengan berbagai pertimbangan. Tetapi bagi tokoh yang bersekolah di tanah air seperti Bung Karno, mereka akan setuju dengan bentuk negara kesatuan karena negara kesatuan dianggap sebagai sebuah bentuk integrasi bangsa. Ide negara kesatuan sendiri dibawa oleh Prof. Soepomo yang mendasarkan pemikirannya berkaca pada bentuk negara Jerman di bawah Hitler dan Jepang saat dipimpin oleh Tenno Haika (Yamin, 1959). Pemikiran awal Soepomo ini sendiri sebenarnya ditentang oleh Yamin karena beranggapan bahwa negara integralistik tidak akan menjamin ditegakkannya HAM sedangkan yang terpenting adalah bagaimana nilai - nilai HAM mampu ditegakkan. Soepomo berpendapat bahwa pada dasarnya negara di dunia ini didirikan atas tiga teori (Yamin, 1959). Yang pertama adalah yaitu teori individualistik dimana negara terbentuk atas dasar kontrak politik yang ada di antara masyarakat itu sendiri. Kedua, teori kelas yang menganggap bahwa negara diciptakan sebagai alat yang digunakan oleh suatu golongan untuk menindas golongan yang lain. Sedangka teori yang ketiga yaitu teori integralistik dimana negara tidak menjamin kepentingan perorangan maupun kepentingan kelompok, tetapi 
negara mencakup kepentingan seluruh komponen. Dan negara di definisikan sebagai sebuah susunan masyarakat yang integral dimana setiap golongan yang ada memiliki ikatan yang erat dan berhubungan satu sama lain dan masyarakat tersebut merupakan susunan yang organis (Yamin, 1959).

Paham integralistik inilah yang menjadi dasar Soepomo merumuskan bentuk negara. Ide ini kemudian disetujui oleh Yamin. Dalam sidang BPUPKI, Yamin mengusulkan bahwa bentuk negara yang sesuai dengan karakter negara Indonesia adalah negara kesatuan bukanlah negara serikat. Yamin juga menegaskan bahwa desain negara Indonesia adalah negara persatuan yang tidak terpecah dan tidak terbagi bagi. Alasan Yamin dalam menolak paham federalisme adalah karena pertama, negara federal diyakini lebih membutuhkan banyak pegawai dibandngkan negara kesatuan. Kedua, negara federal dianggap akan mengarah pada perpecahan sedangkan negara kesatuan akan memperkuat persatuan dan kesatuan bangsa. Ketiga, federalisme dianggap akan melemahkan Indonesia dan bentuk yang pas bagi perjuangan revolusi bangsa Indonesia adalah bentuk negara kesatuan.

Namun gagasan mengenai bentuk negara kesatuan ini tidak serta merta diterima oleh tokoh gerakan yang lain. Salah satu yang tidak mendukung pendapat Soepomo ini adalah Moh. Hatta yang lebih menghendaki bentuk negara federal. Alasan yang diungkapkan adalah karena Indonesia terbagi atas beberapa pulau dan golongan sehingga setiap golongan perlu mendapatkan otonomu dan hak untuk menentukan nasibnya sendiri. Sedangkan kebebasan untuk menentukan nasibnya sendiri tidak ditemukan dalam prinsip - prinsip negara kesatuan. Indonesia yang terdiri dari masyarakat majemuk membuat bentuk federal dianggap lebih mampu untuk mempersatukan bangsa Indonesia.

Pada akhirnya berdasarkan hasil pemungutan suara yang dilakukan dalam Sidang BPUPKI, para pengusung ide federalisme tidak mendapatkan suara mayoritas sehingga diputuskan bahwa bentuk negara Indonesia adalah negara kesatuan. Hal ini kemudian tercantum dalam UUD 1945 Pasal 1 ayat 1. Walaupun sudah diputuskan tetapi beberapa kalangan takut bahwa bentuk ini akan berubah kembali sehingga pada amandemen keempat dipertegas dalam pasal 37 ayat 5 bahwa bentuk negara tidak bisa dirubah. Namun sebenarnya perdebatan mengenai bentuk negara tidaklah pernah usai. Karena pada dasarnya permasalahan mengenai bentuk negara kesatuan maupun negara federal bukanlah permasalahan 
baik buruk karena itu adalah pilihan politik yang diyakini oleh para penggagas kemerdekaan saat itu

Sampai saat ini, bentuk negara kesatuanlah yang terus dipakai oleh Indonesia. Bahkan bentuk negara disebut - sebut sebagai jargon : "NKRI Harga Mati”. Dengan adanya tulisan ini, penulis mencoba menawarkan kembali konsep federalisme sebagai pengembangan keilmuan terkait bentuk negara.

\section{B. TEORI (Literature Review)}

Negara kesatuan adalah sebuah bentuk negara dimana pada awal pembentukannya para pendiri negara mendeklarasikan klaim akan seluruh wilayahnya menjadi bagian dari sebuah negara, dengan kata lain negara tidak dibentuk berdasarkan dengan kesepakatan sebelumnya. Selain itu di dalam negara kesatuan juga dikenal adanya prinsip pelimpahan kewenangan dari pusat untuk sebagian di kelola daerah (Huda, 2004). Walaupun begitu hanya ada satu pemerintahan saja di dalam negara kesatuan ini. Posisi pemerintah pusat dan pemerintah daerah di negara kesatuan tidaklah sama dan sederajat, karena pusat memiliki kekuasaan yang lebih banyak dibandingkan dengan daerah. Selain itu kekuasaan pusat untuk membuat UU tidak bisa digugat oleh lembaga manapun. Lebih lanjut, pemerintah daerah hanyalah bersifat derivatif, maksudnya adalah negara kesatuan tidak mengenal adanya negara di dalam negara dan kekuasaan yang berada di tangan pemerintah daerah hanya merupakan mandat atau wewenang dari pusat dan hukum daerah tidak bisa bertentangan dengan hukum nasional (Saragih, 2000).

Dalam penerapannya di Indonesia, bentuk negara kesatuan ini dilakukan dalam beberapa macam tata kelola pemerintahan. Secara umum terbagi menjadi dua yaitu sentralisasi dan desentralisasi. Desentralisasi ini dapat dijelaskan lagi menjadi dekonsentrasi, desentralisasi maupun tugas pembantuan. Sentralisasi salah satunya dapat dilihat pada masa orde lama,dengan pusat kekuasaan utama hanyalah di tangan Soekarno. Orde lama merupakan periode penting dimana sistem pemerintahan Indonesia berganti dari yang awalnya sistem pemerintahan presidensial berganti menjadi sistem pemerintahan parlementer. Dalam sistem pemerintahan parlementer ini Soekarno sebagai Kepala Negara mengangkat Sutan Syahrir sebagai Perdana Menteri. Sebagai seorang pemimpin, Soekarno merupakan pemimpin yang otoriter dan menggunakan birokrasi sebagai alat mempertahankan kekuasaan. Pemerintahan dijalankan melalui 
mekanisme reward and punishment, pragmatis dan tidak memikirkan kepentingan rakyat yang lebih besar. Soekarno tidak membagi kekuasaannya pada pihak lain dan daerah hanyalah menerima mandat dari pusat untuk menjalankan apa yang menjadi perintah pusat. Kekuasaan terpusat pada presiden dan Soekarno sangat dominan dalam setiap pengambilan keputusan yang dijalankan di dalam pemerintahan

Sentralisasi pada masa orde baru dilakukan lebih buruk daripada yang dilakukan masa orde baru. Ada beberapa tantangan utama yang dijalankan oleh orde baru (Hendityo, 1990). Pertama adalah bagaimana membangun legitimasi sebagai penguasa, kedua, bagaimana membangun stabilitas demi pembangunan dan yang ketiga adalah bagaimana membangun kekuasaan sebagai pemerintah pusat yang mempunyai kewenangan di daerah - daerah. Untuk mencapai ketiganya maka rezim orde baru melakukan use of authority yang besar, luas dan kuat daripada freedom for subordinate (Utomo, 1998), yang kemudian menciptakan pemerintahan yang sentralistis.

Pemerintahan sentralistis ditandai dengan adanya pemerintahan dijalankan dan dikontrol sepenuhnya oleh Soeharto. Seluruh kebijakan yang hasilkan pemerintah baik itu kebijakan yang akan dijalankan di
Pulau Jawa maupun di luar Pulau Jawa dirumuskan seluruhnya oleh Jakarta. Posisi pemerintah pusat dan pemerintah daerah tidak setara dan pemerintah daerah berada di bawah pemerintah pusat. Akibatnya pemerintah daerah tidak berhak melakukan sesuatu yang bertentangan dengan apa yang sudah ditentukan oleh pemerintah pusat.

Sentralisasi juga di tandai dengan terpusatnya pembangunan hanya di Pulau Jawa. Akibatnya terjadi kesenjangan yang sangat tinggi antara pembangunan di Pulau Jawa dengan di luar Pulau. Pembangunan ini hanya terkonsentrasi di Jawa. Semua bidang kehidupan berbangsa dan bernegara baik itu politik, sosial, ekonomi, budaya, dll diatur secara sentral dari pusat pemerintahan. Pusat pula yang menentukan pola distribusi yang akan dilakukan. Akibatnya terjadi ketimpangan luar biasa dan ketidakpuasan di beberapa daerah. Tetapi mereka tidak bisa mengkritik penguasa saat itu karena memang saluran kritik ditutup oleh pemerintah.

Karakteristik pemerintahan sentralistis yang lain adalah lembaga kepresidenan terlalu mendominasi jalannya pemerintahan. Presiden berhak untuk mengelola negara sesuai dengan yang dia inginkan. Akibatnya kebijakan - kebijakan yang dihasilkan pun hanyalah kebijakan yang memang hanya menguntungkan salah satu 
presiden dan mereka yang pro dengan presiden saja. Bahkan pejabat - pejabat yang ada di daerah dipilih langsung oleh presiden saat itu. Inilah yang mengakibatkan tingginya angka KKN karena semua orang akan melakukan apa saja asalkan presiden suka. Tidak hanya dalam bidang kebijakan presiden mendominasi, presiden bahkan mendominasi lembaga - lembaga tinggi lainnya. MPR yang merupakan lembaga tertinggi negara saat itu dapat di kuasai presiden dengan cara menempatkan orang - orang yang Pro Soeharto sehingga proses legislasi pun menjadi executive heavy tanpa mendengar dari pihak lain. Penempatan orang - orang pro Soeharto di dalam parlemen tentunya bukan tanpa proses rekruitmen. Rekruitmen tetap dijalankan hanya saja sifatnya tertutup dan mereka yang terpilih memang benar - benar akan melakukan segala sesuatu untuk Soeharto. Karakteristik pemerintahan yang paling mencirikan Orde Baru adalah pemerintahan otoriter yang dilangsungkan selama 32 tahun. Walaupun sistem pemilu ada dan dijalankan setiap 5 tahun sekali, tetapi itu hanyalah formalitas dalam rangka pemenangan ulang Soeharto

Oleh karena itu maka tuntutan utama yang didesakkan pada orde baru (yang kemudian memunculkan reformasi) adalah adanya distribution of power, sharing of income dan kemandirian sistem pemerintahan di daerah (Larasati, 2015). Hal ini sejalan dengan adanya agenda reformasi yang mana diantaranya adalah perubahan konstitusi (dalam rangka dispersion of power) dan pemberian otonomi daerah (terkait dengan sistem pemerintahan di daerah).

Pasca reformasi, tata kelola pemerintahan yang tadinya sentralistis ini berubah menjadi desentralisasi. Desentralisasi di Indonesia dijalankan dengan sistem pemberian wewenang pada daerah untuk mengurusi urusan urusannya tetapi urusan ini sudah ditentukan oleh pusat mengenai apa yang harus di kerjakan. Hal ini sekali lagi menegaskan konsep negara kesatuan yang di jalankan oleh Indonesia. Rondinelli (1981) mengungkapkan bahwa desentralisasi adalah pemindahan wewenang perencanaan, pembuatan keputusan, dan admnisitrasi dari pemerintah pusat kepada organisasi-organisasi lapangannya, unit-unit pemerintah daerah, organisasi-organisasi semi otonom, pemerintah daerah dan non pemerintah daerah (Koirudin, 2005).

Pemberian otonomi kepada kabupaten/kota yang ditunjukkan dengan Undang-undang No.22 Tahun 1999 tentang pemerintahan daerah. Secara umum undangundang ini berusaha untuk menantang kepala daerah yang 
sudah mulai jelas dalam pengembangan visi, kebijakan, dan program terkait pembangunan daerah. Kepala Daerah Tingkat I tidak lagi dirangkap oleh kepala wilayah, namun Gubernur tetap menjadi wakil pemerintah pusat di daerah yang memiliki tugas mengkoordinasi, mengawasi, melakukan supervisi, dan memfasilitasi agar kabupaten/kota dapat melaksanakan otonomi yang maksimal. Namun ternyata tetap terjadi ketimpangan yang mengakibatkan belum optimalnya fungsi pemerintaham. Salah satu isi UU No.22 Tahun 1999 menyebutkan bahwa "Negara Indonesia terdiri atas daerah dan daerah kabupaten/kota" menyebabkan pembangkangan bupati atau walikota kepada gubernur karena merasa mereka adalah sejajar dan tidak ada hierarki pemerintahan.

Meskipun pada awal penerapannya masih terdapat bias dalam penerjemahan isi UU No.22 Tahun 1999, undang-undang ini tetap diharapkan akan membawa Indonesia ke pemerintahan yang baru dan lebih baik. Lebih lanjut, terdapat lima kebaharuan yang ditampilkan oleh undang-undang ini, yaitu a) demokrasi dan demokratisasi. UU No.22 Tahun 1999 menyebutkan dua hal utama yaitu masalah rekruitmen pejabat daerah dan proses legislasi daerah. UU ini memberikan kewenangan sepenuhnya kepada masyarakat di daerah yang tercermin dalam
DPRD setempat dan tidak ada campur tangan dari pemerintah pusat. b) mendekatkan Rakyat dan Negara. Daerah tingkat II menjadi fokus utama dalam UU tersebut. Hal ini dimaksudkan agar rakyat lebih mudah dan dekat dalam berinteraksi dengan pemerintah. c) sistem Otonomi yang Luas dan Nyata. Jika UU No.5 Tahun 1974 menekanankan asas nyata, dinamis dan bertanggungjawab, maka UU No.22 Tahun 1999 lebih menekankan pada asas luas dan nyata. Hal ini dimaksudkan agar daerah dapat secara maksimal menggunakan hak dan bertanggungjawab atas kesejahteraan daerah masingmasing. d) tidak menggunakan Sistem Otonomi Bertingkat. Gubernur tidak lagi merupakan atasan dari Bupati atau Walikota. Ketika Provinsi menyelenggarakan urusan-urusan yang bersifat lintas kabupaten atau kota, sebenarnya adalah daerah tingkat II dapat dikatakan sudah mampu menyelenggarakan tanpa bantuan dari provinsi. e) no mandate without funding. Persoalan pembiayaan adalah persoalan yang sangat penting bagi pelaksanaan otonomi daerah. Penyelenggaraan tugas pemerintah di daerah harus dibiayai APBN (Gaffar, 2000). Adanya beberapa karakter tersebut paling tidak juga memunculkan semangat daerah untuk menjadi daerah otonomi yang baik. Sehingga kesejahteraan masyarakat dapat tercapai dengan 
kekuatan yang dimiliki daerah yang berdasarkan pada UU No.22 Tahun 1999 tersebut.

Belum genap 5 tahun penerapan UU No.22 Tahun 1999, pemerintah sudah mengeluarkan revisi atas UU tersebut yaitu UU No.32 Tahun 2004. Revisi ini dilakukan untuk menyegarkan kembali otonomi daerah yang mengandalkan kemandirian dan kemajuan daerah. Namun revisi UU No.22 Tahun 1999 ini diragukan beberapa pihak dan diartikan sebagai upaya untuk kembali menjadi sentralisasi (Koirudin, 2005). Pada dasarnya asas dan tujuan UU No.32 Tahun 2004 ini masih tetap menganut desentralisasi. Namun terdapat satu hal yang oleh beberapa kalangan dianggap sebagai unsur kuat akan terjadi sentralisasi kembali (resentralisasi) yaitu penggunaan istilah urusan kewenangan. UU No.5 Tahun 1974 menggunakan istilah urusan pemerintahan dan tidak pernah menggunakan istilah kewenangan pemerintahan, yang sekarang terulang kembali pada UU No.32 Tahun 2004.

Kecurigaan tersebut sebenarnya bukanlah hal utama yang harus terus diperdebatkan. Banyak hal yang harus dilakukan apalagi terkait dengan perbaikan sistem pemerintahan di daerah. Apalagi dengan adanya hal-hal baru yang muncul pada UU No.32 Tahun 2004, antara lain adalah pemilihan kepala daerah (Pilkada) langsung oleh rakyat, pembentukan daerah dan kawasan khusus, dan semakin jelasnya urusan yang diberikan oleh pusat ke daerah yang bertujuan untuk menciptakan pemerintahan yang efektif dan efisien. Beberapa hal tersebut tentu akan berdampak pada perubahan lembaga pemerintahan di daerah, entah pada struktur ataupun sistem kerja mereka.

Pada perkembangannya kemudian muncul UU No 23 tahun 2014. Penyerahan kewenangan ke daerah didetailkan menjadi urusan pemerintahan absolut, urusan pemerintahan konkuren, dan urusan pemerintahan umum. Urusan ini pada UU sebelumnya hanya dibedakan menjadi urusan wajib dan urusan pilihan saja. Hal ini berdampak pada pembagian kewenangan dari pemerintah pusat ke pemerintah daerah yang tidak mendetail. Urusan pemerintah absolut adalah urusan pemerintahan yang sepenuhnya menjadi kewenangan pemerintah pusat, yang dapat dilimpahkan urusannya kepada instansi vertikal. Sedangkan urusan pemerintahan konkuren adalah urusan pemerintahan yang dibagi antara pemerintah pusat dan pemerintahan daerah baik provinsi maupun kabupaten/kota. Sedangkan urusan pemerintahan umum adalah urusan terkait bidang pengawasan dan pembinaan terhadap wawasan bangsa, ketahanan nasional, 
Vol.1 No.1 Juni 2019

pembinaan persatuan dan kesatuan bangsa.

dapat dilakukan oleh pemerintah pusat pada pemerintah daerah.

\section{METODE}

Penelitian ini bersifat kualitatif menggunakan metode desk-research. Metode deskresearch (penelitian kepustakan) menggunakan sumber-sumber yang tersedia di publik, seperti media elektronik, surat kabar, buku, laporan riset, dan jurnal. Nantinya, metode ini menganalisis dengan landasan teori yang relevan.

\section{HASIL DAN PEMBAHASAN}

Berdasarkan dinamika yang terjadi saat ini, termasuk alasan alasan bahwa pemerintah pusat tidak bisa mengakomodasi apa yang menjadi kebutuhan daerah, ketimpangan pembangunan pulau Jawa dan luar Pulau Jawa, ketidakmampuan pemerintah mengelola keberagaman yang ada di Indonesia, muncul wacana mengenai perubahan bentuk negara Indonesia menjadi federal. Wacana ini sempat ditolak keras oleh beberapa kalangan karena dianggap sebagai sarana pemecah belah persatuan bangsa. Tokoh yang di kecam keras karena membawa ide tentang federalisme ini salah satunya adalah Amien Rais. Terlepas dari tidak diterimanya wacana federalisme karena dianggap tabu, wacana ini sebenarnya mampu memberikan pola pemahaman baru mengenai bagaimana penataan ideal yang negara kesatuan yang hanya mengenal satu pemerintahan resmi, federalisme meyakini adanya dua pemerintahan resmi yaitu pemerintahan di negara federal dan pemerintahan di negara bagian, hal inilah yang kemudian menjadi ciri utama dari negara federal. Ada dua macam syarat negara menjadi sebuah federasi. Yang pertama ada 'perasaan nasional' diantara negara bagian dan kedua ada keinginan untuk membentuk persatuan dan bukan kesatuan. Perasaan nasional inilah yang mendasari sebuah negara untuk bergabung ke dalam sebuah federasi. Perasaan nasional ini menjadi penting karena negara federal pada dasarnya dibentuk oleh negara - negara merdeka yang sepakat bersatu untuk membentuk pemerintahan yang baru tetapi masing - masing tidak meleburkan kekhasan mereka. Perasaan nasional ini terbentuk biasanya karena mereka memiliki kesamaan seperti bahasa ibu yang sama maupun tanah kelahiran yang sama. Persamaan persamaan inilah yang menyatukan mereka. Jika tidak ada persamaan dan perasaan nasional, maka sudah dapat dipastikan bahwa federasi akan sulit dibentuk.

Ada 8 ciri dasar yang dapat digunakan untuk mengidentifikasi 
negara federal (Larasati, 2015). Pertama adalah bagian dari federasi seperti misalnya negara bagian terlibat dalam pengambilan keputusan di tingkat nasional. Tidak seperti negara kesatuan, dimana daerah tidak memiliki pengaruh di pusat tetapi di dalam federasi keterlibatan negara bagian justru menjadi keniscayaan dalam setiap proses decision making. Hal ini kemudian terkait dengan ciri yang kedua yaitu adanya sistem perwakilan wilayah di nasional. Maksudnya adalah setiap negara bagian menempatkan wakilnya di nasional. Wakil - wakil inilah yang akan membawa kepentingan negara bagian. Mereka memiliki tugas untuk memastikan bahwa di setiap keputusan yang di buat di pusat akan selalu mempertimbangkan kebutuhan di masing - masing negara bagian. Jumlah negara bagian ini tergantung dari kebijakan masing masing negara. Di Jerman, jumlah wakil ini disesuaikan dengan jumlah penduduk yang ada di dalam sebuah negara bagian, tetapi di Amerika Serikat setiap negara menempatkan wakilnya dengan jumlah yang sama.

Ciri ketiga adalah masuk atau keluarnya negara bagian di dalam federasi akan melalui mekanisme yang rumit seperti misal perubahan kosntitusi. Hal seperti ini tidak akan ditentukan dengan prinsip pengambilan keputusan sederhana seperti voting dengan ketentuan suara $50 \%+1$ akan dianggap sebagai suara yang sah. Hal ini dikarenakan setiap hak dan kewajiban termasuk dengan tugas - tugas yang harus dilaksanakan oleh negara bagian sudah tertulis dengan rigid di dalam konstitusi negara federal. Keempat, dibentuk sebuah lembaga tertinggi yang bertugas untuk menyelesaikan sengketa baik antara negara bagian maupun negara bagian dengan negara federal. Sengketa menjadi sebuah fenomena yang tidak mungkin dapat terhindari, oleh karena itu kehadiran lembaga seperti supreme of court menjadi penting dan sangat dibutuhkan demi menjaga netralitas dalam penyelesaian konflik yang ada.

Hal ini terkait dengan ciri kelima yaitu adanya supremasi konstitusi. Keenam, adanya dua konstitusi yang digunakan. Konstitusi pertama yaitu konstitusi negara federal yang mengikat negara - negara bagian dan konstitusi yang kedua adalah konstitusi yang dirumuskan dan dijalankan di negara bagian. Konstitusi negara bagian ini bisa berbeda antara satu negara dengan negara yang lainnya tergantung setting sosial dan budaya yang ada di negara tersebut. konstitusi antara negara bagian dan negara federal ini disusun bertingkat. Inilah yang menjadi ciri ketujuh Tingkatan ini maksudnya adalah memisahkan tentang urusan yang hanya bisa 
diurusi negara federal seperti pertahanan keamanan, moneter, agama, dan pos dan urusan yang bisa diurusi negara bagian seperti kesehatan, pendidikan, dll. Sehingga tidak terjadi tumpang tindih kekuasaan. Kedelapan adalah adanya distribusi kekuasaan antara negara federal dengan negara bagian. Negara federal tidak berhak mengontrol apa yang terjadi di dalam negara bagian tetapi negara bagian juga harus memiliki batasan yang mengatur kekuasaannya agar tidak terjadi konflik dengan negara bagian yang lainnnya.

Secara tidak sadar praktek semi federalisme ini sebenarnya sudah diterapkan di indonesia. Hanya saja nilai - nilai yang diterapkan belumlah mampu dijalankan sepenuhnya. Hal ini terbukti dengan pemberlakuan otonomi daerah. Walaupun begitu kebebasan mengelola daerah sesuai dengan kebutuhan daerah tidak diberikan secara bebas seperti yang terjadi di dalam negara federal. Jika dilihat secara mendalam, sebenarnya prinsip prinsip federalisme bisa dilaksanakan di Indonesia. pertama, misalnya terkait dengan pembentukan federasi. Federasi yang dibangun di Indonesia sebenarnya bisa di dasarkan dari dua hal. Yang pertama di dasarkan pada kondisi geografis yang berarti federasi dibangun atas dasar pulau - pulau yang ada di Indonesia. hal ini membawa keuntungan dan kerugian masing - masing. Keuntungannya adalah batas antar negara federal sudah jelas karena dipisahkan oleh lautan tetapi kerugiannya peluang terkonsentrasinya pembangunan di Pulau Jawa akan bisa terulang. Hal ini dikarenakan para akademisi dan ahli akan terkonsentrasi di Pulau Jawa dan mereka hanya akan membangun daerah asal mereka sendiri. Dasar pembentukan yang kedua adalah berbasiskan identitas. Identitas ini bisa berupa macam - macam seperti misal Indentitas kesukuan, agama, maupun identitas lain seperti LGBT, difabel, dll. Namun jika berdasarkan kesukuan ini maka peluang adanya egosentrisme akan sangat kuat karena setaip orang akan berjuang hanya demi kelompoknya saja tanpa memperhatikan kelompok yang lain.

Kedua, terkait dengan konstitusi. Indonesia sendiri sebenarnya sudah menjalankan double konstitusi dengan prinsip desentralisasi yaitu adanya penyerahan wewenang berupa urusan wajib yang harus dijalankan oleh daerah dan urusan pilihan yang dijalankan sesuai dengan kondisi daerah. Perlemen pun sudah terbagi menjadi dua yaitu parlemen di tingkat nasiona (DPR RI) dan parlemen di tingkat daerah (DPRD Provinsi dan DPRD Kabupaten). Perwakilan masing masing daerah pun sudah tertampung dalam DPD dimana 
Vol.1 No.1 Juni 2019

masing - masing daerah mengirimkan wakilnya untuk duduk di kursi DPD. Secara ekstrim, Indonesia hanya perlu melakukan perubahan konstitusi dan mendirikan Supreme of Court dan jadilah Negara Federal Indonesia karena selama ini tanpa disadari bentuk negara kesatuan yang dijalankan adalah semi federalisme.

\section{E. SIMPULAN DAN SARAN}

Pada dasarnya kehadiran federalisme membawa 5 nilai positif yang apat digunakan sebagai bahan pertimbangan dalam rangka menimbang federalisme menjadi bentuk negara baru di masa datang yang dianggap ideal. Pertama, pengelolaan negara nonsentralistis. Pusat - pusat kekuasaan yang tersebar tidak hanya dipegang oleh pemerintah pusat saja tetapi juga dberikan ke daerah. Kekuasaan ini tidak hanya berbicara pad akemampuan negara untuk menjalankan instruksi dari pusat seperti yang terjadi di dalam sentralisasi tetapi kemampuan daerah untuk mengelola bagiannya sendiri secara luas dan bertanggungjawab. Selain itu, walaupun satu daerah terpisah dengan daerah yang lain, posisi mereka adalah setara sehingga tidak bisa saling menjatuhkan. Kebaikan kedua adalah federalisme dianggap sebagai sistem yang lebih demokratis karena posisi rakyat dan pemerintah lebih dekat dibandingkan sistem sentralistis. Kedekatan inilah yang kemudian mendorong keterlibatan rakyat di dalam setiap kegiatan bernegara. Kebaikan yang ketiga adalah adanya sistem check and balances yang jelas. Sistem ini diatur di dalam konstitusi negara federal yang memuat dengan rinci apa saja yang mengatur negara bagian. Aturan yang rigid inilah yang membatasi 'ambisi' negara bagian satu pada negara bagian yang lain. Kebaikan yang keempat adalah adanya open bargaining. Proses tawar menawar dilakukan secara terbuka di dalam semua arena politik, semua institusi maupun semua badan perwakilan. Proses ini didapat diakses oleh siapa pun karena sistem negara federasi memberikan jaminan kebebasan untuk hal tersebut. Dan kebaikan yang kelima adalah adanya konstitusi yang rinci. Konstitusi ini memuat semua framework kekuasaan yang dituliskan dan dimaknai dengan interpretasi yang sama antara satu pihak dengan pihak yang lain.

Kebaikan - kebaikan inilah nantinya akan di dapat jika Indonesia menggunakan bentuk negara federalisme. Banyak yang mempertanyakan mengapa harus berubah ke federalisme jika semuanya dapat didapat dengan mekanisme desentralisasi. Tetapi yang perlu menjadi catatan adalah di dalam desentralisasi, kekuasaan di level lokal selalu dibatasi hanya 
dapat digunakan di dalam urusan lokal dan urusan ini diatur secara ketat oleh pusat. Urusan lokal ini juga dapat diperiksa ulang, dibatasi hingga ditarik kembali oleh pemerintah pusat. Sedangkan di dalam federalisme, kekuasaan tidak dapat ditarik ke dalam negara federal. Semoga makalah ini mampu memberikan gambaran yang positif mengenai federalisme, sehingga wacana ini pun tidak lagi dianggap sebagai wacana tabu dan yang memperbincangkan akan dikecam karena mengancam integrasi bangsa Indonesia

\section{DAFTAR PUSTAKA}

Budiardjo, Miriam (2008) Dasardasar Ilmu Politik (edisi revisi). Jakarta : Gramedia Pustaka Utama

Hendytio, Madelina K (1990). Masalah Desentralisasi pada Masa Orde Baru. Analisis CSIS

Huda, Ni'matul (2004). Sejarah Ketatanegaraan Indonesia, Pilihan atas Federalisme atau Negara Kesatuan, dalam Edy Suandi Hamid dan Sobirin Malian, Memperkokoh Otonomi Daerah : Kebijakan, Evaluasi dan Saran. Yogyakarta : UII Press

Koirudin (2005). Sketsa Kebijakan Desentralisasi di Indonesia: Format Masa Depan Otonomi Menuju Kemandirian Daerah. Malang: Averroes Press
Kusnardi, M dan Saragih, Bintan R (2000). Ilmu Negara. Jakarta : Gaya Media Pratama

Strong C.F. (2010). Konstitusikonstitusi Politik Modern : Suatu Perbandingan tentang Sejarah dan Bentuk. Bandung : Nusa Media

Sularto dan Yunarti, D. Rini (2010). Konflik di Balik Proklamasi. Jakarta : Penerbit Buku Kompas

Utomo, Warsito (1998). Sistem Federal dalam Negara Kesatuan, Kasus Pengaturan Desentralisasi-Otonomi. JSP Volume I, No. 3 Maret 1998

Yamin, Muhammad (1959). Naskah Persiapan Undang-Undang Dasar 1945 : Disiarkan dengan Dibubuhi Catatan. Jakarta : Prapantja 